\title{
Deliberative communication: a pragmatist proposal
}

\author{
TOMAS ENGLUND
}

\begin{abstract}
This paper seeks to make use of later works of Habermas in the field of education. The theme, developed out of the pragmatic tradition, is that of deliberative communication as a central form of activity in schools. This implies a displacement of traditional teaching and learning as the central form of activity to the creation of meaning through deliberative communication. Deliberative communication can be understood as an endeavour to ensure that each individual takes a stand by listening, deliberating, seeking arguments, and evaluating, while at the same time there is a collective effort to find values and norms on which everyone can agree.
\end{abstract}

Keywords: creation of meaning; deliberative communication; Habermas; modernity; normative rationalization; Swedish education.

Modernity can and will no longer borrow the criteria by which it takes its orientation from the models supplied by another epoch; it has to create its normativity out of itself. (Habermas 1990: 7)

\section{Introduction}

What would a democratic conception of education look like today? ${ }^{1}$ In trying to develop a democratic conception of education, I draw on the pragmatic tradition (Englund 1996). Thus, neo-pragmatism focuses on communication as a democratic way of life. It creates new visions for the relationship between democracy and education through communication (Englund 2000a). Many works on deliberative democracy are also inspired by pragmatism, especially Dewey's (1984) The Public and its Problems, and are explicitly based on the need for the education of citizens in deliberative capabilities and attitudes (Gutmann and Thompson 1996). Thus, an ongoing deliberative democracy requires citizens with well-established deliberative attitudes, and a society that rests on the ideas of deliberative democracy is a long-term project: 'democratic deliberation requires equal opportunity of access to political influence' (Knight and Johnson 1997: 280; emphases in original). This implies that some institutions are given a central role, with the educational system holding, perhaps, the most

Tomas Englund is professor of education in the Department of Education, Örebro University, S-70182 Örebro, Sweden; e-mail: tomas.englund@pi.oru.se. His research interests centre on curriculum theory and didactics, curriculum history, political socialization and citizenship education, and the philosophical aspects of education. He directs the research group Education and Democracy and is co-editor of the Swedish journal with the same name (in Swedish, Utbildning $\mathcal{E}$ Demokrati). His most recent book is Skillnad och konsekvens [Difference and consequences] (Lund, Sweden: Studentlitteratur, 2004). 
important potential in such a long-term project. It can lay the foundations for developing deliberative capacities. Furthermore, one of the long-term ends-in-view to be achieved by giving deliberative communication a prominent place is developing the democratic role of the school system: 'In any effort to make democracy more deliberative, the single most important institution outside government is the educational system' (Gutmann and Thompson 1996: 359).

In the current debate on legitimacy and public space, numerous uses of the word 'deliberative' may be noted, most of them directly related to democracy. In the US, for example, there is a vast literature within political science on the subject of deliberative democracy. The German philosopher and sociologist Habermas also holds a central place within the current debate. His Between Facts and Norms (Habermas 1996) and several of his other works have given scholars some basic starting points for an analysis of the relationship between society and education within a perspective of normative rationalization, i.e. the transformation of the source of the sacred to communication as collective will-formation. In this perspective, what ultimately explains social integration is communicative and argumentative consensual processes. It is the good argument that creates validity, a validity that also has an integrative force.

Habermas's (1984, 1987) theory of communicative action, further developed into a model for deliberative democracy and a discourse theory of law and democracy (Habermas 1996), is perhaps the most highly developed and best-known theory of deliberative democracy (Bohman and Rehg 1997). The implications of this model for education are not explicit, and Habermas can be interpreted in different ways. In the interpretation presented in this paper, I use central elements of Habermas's theory and, in line with the critique of Habermas by Fraser (1992) concerning public spheres for deliberation, I see schools as potential 'weak publics', potential public spaces in which there is a preference for pluralism.

In this paper, I first give a background to the idea of deliberative communication in Swedish schools. Secondly, I present the sources of inspiration for the idea-both the US pragmatists Dewey and Mead and the German pragmatist Habermas are key figures. I also relate my idea to the broader movement of deliberative democracy. Finally, I present five characteristics of deliberative communication.

\section{The deliberation concept and the Swedish situation}

In efforts to develop what has come to be called 'the democratic foundation of schools' in Sweden, the idea of 'deliberative communication' has occupied a prominent position. Thus, both the Ministry of Education (2000) and the National Agency for Education (2000) have advocated deliberative communication as a central form of activity in schools. Deliberative communication is understood in this context as communication in which different opinions and values can be brought face to face, 
[with] an endeavour to ensure that each individual takes a stand by listening, deliberating, seeking arguments and evaluating, while at the same time there is a collective effort to find values and norms that everyone can agree upon. (National Agency for Education 2000: 6; my translation)

What does the idea of deliberative communication mean in relation to the school's main task of transmitting knowledge? Is deliberative communication a challenge to this task? In certain circles it may be seen in that light, in the same way as earlier attempts to make the democratic task of schools concrete in terms of their overriding goals, etc., have been looked upon as disturbing aspects of schools' primary task of transmitting knowledge. Looking at the democratic task in that way and seeing deliberative communication as competing with the task of knowledge-transmission is also the perspective that seems to have priority in the general debate. However, I find this perspective both unfortunate and misleading, although it is the classical contradiction between knowledge-transmission and socialization/personal development that has been propagated in an educational debate in which the leading Swedish mass-media organ, Dagens Nyheter, has the power and privilege to formulate what the problem is.

The potential force of deliberative communication is, as I see it, not only that it can contribute to the formation of values and knowledge directly related to the democratic foundation of schools. Deliberative communication (used in an appropriate way) can also contribute to meaning-creation and knowledge-formation among students in most subject areas, even within traditional school subjects and areas that seem to be a long way from subjects closer to the democratic foundation of schools.

It is also important to emphasize that the democratic foundation of schools can be conceptualized in different ways, and that deliberative communication is just one of many ways of achieving the foundation that has been proposed. There is an obvious tension between two substantial traditions when it comes to conceptualizing the democratic foundation of schools, one of which regards democracy as the central concept, while the other emphasizes 'the ethics nurtured by Christian tradition and Western humanism' (Lpo 1994: 5; my translation). Secondly, the idea of deliberative communication can be conceptualized as challenging value-traditions that have been prominent for a long time, e.g. goals expressed in terms of tolerance, freedom, solidarity, etc., as well as the inalienable rights of the human being, legitimated by reference to the ethics nurtured by Christian tradition and Western humanism. All these variants of substantial references can be questioned by a procedurally- and inter-subjectively-oriented conceptualization of the democratic foundation of schools, interpreted as one that makes room for deliberative communication. Unlike a substantial perspective, a procedural perspective can emphasize that the democratic foundation of schools is primarily procedural. Then the need to define the democratic foundation of the schools, but now in procedural terms, has to be considered.

The word 'deliberative' is first explicitly developed in the ethics and the rhetoric of Aristotle. What we do deliberate about in ethics are the things that depend on ourselves and are doable. 
What we deliberate about and what we decide on are the same, except that what is decided on is, as such, something definite; for it is what has been selected as a result of deliberation that is 'decided on'. (Aristotle 2002: 128)

To have deliberated well is thought to be a good thing; 'for it is this sort of correctness of deliberation that is deliberative excellence, i.e. the sort that enables one to achieve what is good' (Aristotle 2002: 184).

Aristotle divided rhetoric into three genres, seeing deliberation as the common mode of political argumentation in relation to specifically proposed political acts. Deliberation, as discussed in his Rhetoric (Aristotle 1991: chs $4,8)$, focuses on questions of the best or most advantageous (sympheron) course of action. It is oriented towards the future and towards influencing judgements about what should be done. The guiding principle of deliberation is eudaimonia, well-being, happiness, or fulfilment. That is, the most general goal of deliberation was to establish policies and pursue actions that would contribute to the well-being of the citizens of Athens. Deliberation, consequently, is about the factors in civic life which contribute to the public good of the citizenry.

The etymological meaning of 'deliberative' can be derived from the roots of the word, which are the Latin deliberare and libra, meaning 'to weigh' and 'balance'. The concept of deliberation has later been closely related to judicial processes, in the sense of just deliberation between different alternatives, and there are many more precise interpretations of the word in that direction. There is an obvious dimension of purposiveness to the concept, in that the deliberative is closely related to balanced and responsible consideration (deliberation).

Deliberation - mutual and carefully-balanced consideration of different alternatives - is in the current literature of political and social science closely coupled to democracy as communication, and hence to a specific way of understanding how democracy can and should be elaborated, i.e. deliberative democracy as a normative political project of a specific communicative character. The fundamental idea of deliberative democracy as a supplement to the majority principle, based on simple voting between alternatives, is that the legitimacy of democracy will be strengthened if different views and perspectives are communicated and discussed in detail (i.e. deliberated upon) by all the different parties and participants involved, and that the different proposed decisions should be carefully motivated. In the deliberation process, the participants involved should reach agreement on what the issue is, what the parties do not agree upon, what the alternative decisions are, and what kind of procedure there is to make a decision. Deliberative democracy also implies that the decisions made are to be seen as temporary and that consensus and non-consensus are present at the same time: temporarily-made decisions are respected and obeyed, while different views are also respected.

The use of the concept 'deliberative' without that of 'democracy' does not imply that the direction of democracy is neglected, but there is an important difference between deliberative communication and deliberative democracy. In the latter constellation, a close relationship to one or other formal democratic decision-making process is central, whereas deliberative 
communication does not pre-suppose this closeness. However, it is more a question of a difference of degree than of two clearly distinct phenomena. The second key difference is that deliberative democracy implies in principle (if not in reality) equal citizens. The participants in deliberative communication in the classroom are teachers and students, i.e. individuals with differing knowledge and experience and differences in authority, formal as well as real, deliberating within a 'weak public'.

The long-term object of this paper (and others closely related to it) is to give deliberative communication a prominent position in work relating to what has come to be called 'the democratic foundation of schools', and in the long-run to strengthen democracy. ${ }^{2}$

\section{Deliberative communication-a pragmatist proposal?}

\section{The inter-subjective perspective of Mead and Dewey}

Although the idea of deliberative communication has specific connections to political science and the idea of deliberative democracy, and also to learning theory and the idea of learning in a sociocultural perspective-and I will come back to both of these-I would like first to emphasize the inspiration that has come from the pragmatist movement, and especially from Dewey, Mead, and, later, Habermas. What Dewey and Mead underlined in particular was a view of education as communication. What they emphasized was not, as in the sociocultural perspective, the question of learning, but more the question of meaning and knowledge-formation through intersubjective meaning-creating processes. One of the main theses which Dewey and Mead put forward was that knowledge, or rather meaning, is created in relation to a problem and in social situations where different aspects of the problem are illuminated and one's own habitual view is challenged. They contended that the experiences gained by each participant in meaning-creating processes resulted in the development of the reflexive capacity of both: the self is widened by taking account of the other's perspective and the capacity to engage in judgement processes becomes more nuanced. Furthermore, such meaning-creating processes not only involve knowledge-formation but also the formation of a community through critical communication relating to common and opposing interests.

Among the pragmatists, Mead is the one who tried to construct a theory of human intersubjectivity, a theory that is also one of the central reference points of pragmatism. Although the concept of intersubjectivity is not used by Mead as such, it can be said to be the concept that most obviously reveals the signification of human beings as social and communicative and, more precisely, shows that we create meaning together (von Wright 2000).

As a source of inspiration, Dewey is important in many different respects and on different levels. I draw on two of his works in relation to the idea of deliberative communication. In Democracy and Education, Dewey (1980) elaborates a view of education as communication, which I see as a foundational source of inspiration (Englund 1999b). In this work, he also develops an analysis of the basic elements of communication and the pre-conditions 
for communication as criteria for democracy as a life-form. Dewey took the view that democracy was not primarily a mode of management and control, but more an expression of a society imprinted by mutual communication, and consequently a pluralist life-form. It is in this perspective, too, that Dewey emphasizes the communicative aspects of education and the idea of education as a place for reflection upon common experiences. It is also from Dewey, but now from The Public and Its Problems (Dewey 1984), that we see the idea a democratic society as an open, communicative society in which institutions such as schools serve as public spaces/weak publics that encourage deliberative communication, and in which the public has to define itself (Englund 1996, Ljunggren 1996a, b).

The concept of education which Dewey (1980: 86) introduces is summarized in the idea of a 'continuous reconstruction of experience', and concerning the potential of education he says that

we are doubtless far from realizing the potential efficacy of education as a constructive agency of improving society, from realizing that it represents not only a development of children and youth but also of the future society of which they will be the constituents. (Dewey 1980: 85)

It is also through his emphasis on the relationship between education and democracy as a life-form that Dewey understands education as a forum for communication between people with different experiences. The communicative criteria put forward by Dewey (1980) with the aim of achieving free and open communication between and within groups provide important guidance for the development of criteria for the idea of deliberative communication.

Dewey's work is the basic to the idea of deliberative communication in schools. This is also true of his view that one of the central tasks of education is to develop the capacity of every individual for intelligent deliberation and balanced consideration of alternatives through mutual communication. From the standpoint of the philosophy of education, the idea can also be seen as a manifestation of the idea that it is the task of education to create pre-conditions for students to engage in moral deliberation and to adopt positions in relation to the world, society, and each other (Englund 2000b).

Habermas's discourse theory as a foundation for deliberative democracy and the normative rationalization of society

It is evident that Habermas, the most prominent living source of inspiration for the idea of deliberative communication, is greatly influenced by Mead, and especially as regards the elements of his frame of reference for communication. This inspiration is extended in Habermas (1987), wherein he uses the intersubjective concept of social action that Mead elaborated in his criticism of the concept of the subject developed within classical modernity. Habermas gives this intersubjective concept of social action a central place in his development of a frame of reference for communicative action. The perspective developed by Habermas in relation to Mead is concerned with the foundational concepts-primarily, intersubjectivity and mutual 
action-for normatively-regulated and linguistically-mediated interaction in the perspective of social integration.

The interaction analysis undertaken by Mead - his analysis of the dependence of each individual on the generalized other and the process of 'taking the attitude of the other'-is used by Habermas in a perspective of the child's development and socialization. Habermas emphasizes that these are processes everyone will go through, but can be made different and have differing quality. Habermas (1987) supplements Mead's approach by drawing on Durkheim's analysis of social order. The source of normative rationalization has changed over time, and intersubjective action and human communication offer a specific potential for creating social order in a historical perspective. In his last major work, Durkheim (1961) traces the sacred as the historically dominant source of social cohesion, and he sees science as the possible cohesive force of classical modernity. What Habermas does in his extension of Mead's interaction theory and Durkheim's theory of social order can be seen as a 'linguistification' of the problem of social integration and social order. In other words, social integration is linked to collective, linguistically-based processes of knowledge- and will-formation with regard to what is normatively valid and 'true' in what has come to be called 'the second modernity' (Carleheden 1996). It is the frame of a communicative rationality that creates the normatively valid in the processes which Habermas analyses as socially integrative.

From the standpoint of social and educational philosophy, one could say, with Habermas, that a way of strengthening the pre-conditions for normative rationalization through communicative action would be to promote and use deliberative communication in schools, i.e. to promote social integration through collective volitional and consensual processes about what is normatively valid. However, Habermas can be interpreted in different ways on the implications for education. What can be said is that he places the realization of a deliberative policy in the institutionalization of procedures, where intersubjectivity on a higher level is expected to emerge. Public discourses meet with a good response only under circumstances of broad participation. This, in turn, 'requires a background political culture that is egalitarian, divested of all educational privileges, and thoroughly intellectual' (Habermas 1996: 490). Political autonomy cannot be realized by a person who pursues his or her own private interests, but only as a joint enterprise in an intersubjective, shared practice. On this account, the deliberative project could be regarded as the continuation of the project of modernity.

Habermas's (1984, 1987) theory of communicative action, further developed into a model for deliberative democracy and a discourse theory of law and democracy (Between Facts and Norms, Habermas 1996), is perhaps also the most highly developed and well-known theory of deliberative democracy (Bohman and Rehg 1997). His model is developed in relation to the liberal and the republican/communitarian traditions, and in his analysis he emphasizes the different citizenship concepts of those traditions. Habermas (1996: 271) also stresses how the dichotomized conceptualizations of citizenship rights of these traditions 'fail to grasp the intersubjective meaning of a system of rights that citizens mutually accord one another'. 
In the discourse theory of law and democracy that Habermas (1996) has developed, participatory rights consequently have precedence. In this work, Habermas presents a system of citizenship rights which, in many respects, reminds scholars of the classical system developed by Marshall (1964), in which civil, political, and social or welfare rights come after each other. However, in contrast to Marshall, what Habermas does is see the political participatory rights as the most fundamental: 'Indeed, only rights of political participation ground the citizen's reflexive, self-referential legal standing' (Habermas 1996: 504). The reason for this is the inner connection between the sovereignty of the people and their political participatory rights, which is seen as the medium for the self-determination and self-realization, implying that the political autonomy of citizens cannot be achieved merely by law but in the communication processes of discursive opinion- and will-formation (Englund 2002). These rights are described by Habermas (1996: 123) as 'basic rights to equal opportunities to participate in processes of opinionand will-formation in which citizens exercise their political autonomy and through which they generate legitimate law' (cf. Eriksen and Weigård 2000).

As I have already noted, the consequences for education are not spelt out by Habermas himself, but an authoritative commentator suggests that the perspective put forward in Habermas (1996):

must, looking to the possibilities for change, lead to the development and encouraging of structures within the system of law and to education of deliberative capacities and attitudes among the citizens who will perform this communicative power. (Reese-Schäfer 1995: 82; my translation)

The perspectives presented-Mead on intersubjectivity, Dewey on communication, and Habermas on the realization of a deliberative policy through an institutionalization of procedures - are also linked to the broad movement that has grown during the last 20 years and acquired the name of 'deliberative democracy'. This movement, primarily developed within political science in the US, also has its roots in Dewey's (1984) The Public and Its Problems.

\section{The relationship to deliberative democracy}

An important and contributory factor behind the choice of the word 'deliberative' as a prefix to 'communication' is its presence in the contemporary debate on democracy, more precisely as a qualification of a kind of democracy in terms of explicitly deliberative democracy. ${ }^{3}$

The idea of deliberative democracy is traced by many of its proponents to Aristotle and the polis of ancient Greece, to $19^{\text {th }}$-century political philosophers such as Burke and Mill, but mostly to Dewey's (1984) The Public and Its Problems. In that book Dewey is said to develop the main aspects of the idea of deliberative democracy, namely the need in democracies to communicate, deliberate, and reflect over one's preferences prior to decision-making.

In the debate about democracy that has created the idea of deliberative democracy, the close affinity to what is usually called participatory democracy is obvious. Participatory democracy and deliberative democracy are in 
fact difficult to distinguish and can, of course, be conceptualized differently by their proponents. In a wider perspective of democratic theory, these two terms can be said to express two versions of a normative view of democracy, as opposed to a functionalist view, applying the labels Lewin (1970) uses to differentiate these two main traditions.

The distinctions between participatory and deliberative democracy are contested, and have been elaborated in different ways. Here my primary aim is to discriminate between the two traditions in a general sense and thereby to try to show how they have been and can be used in the context of education (and in my case, primarily in the Swedish context).

One differentiation implies that participatory democracy, to a higher degree than its deliberative counterpart, has a communitarian vein, emphasizes morals and virtues, and has an optimistic faith in the capacities of citizens to participate actively in the processes of democratic decision-making. ${ }^{4}$ The tradition of deliberative democracy has its starting point in deontological intersubjective procedures, and emphasizes rational argumentation and the public debate of questions relating to which different conceptions are obvious. ${ }^{5}$ Gutmann and Thompson (1996; see also Gutman 1987) can be seen as representing a finer balance between the participatory and the deliberative conceptions. Like participatory democracy, deliberative democracy is very much concerned with participation in democratic processes, but deliberative democrats specifically accentuate the character of the processes, with the starting point that different views have to be adjusted or confronted by means of argumentation. Thus, the starting point is the presence of two or more conceptions concerning a specific problem, represented by individuals in a confrontation, where a key demand is openness of argumentation: 'While acknowledging that we are destined to disagree, deliberative democracy also affirms that we are capable of deciding our common destiny on mutually acceptable terms' (Gutmann and Thompson 1996: 361).

Compared to participatory democracy, deliberative democracy especially emphasizes responsibility and consequences, implying that socialization into citizenship and the exercise of citizenship must be in focus. Gutmann and Thompson (1996) put forward three principles for deliberative democracy: reciprocity, publicity, and accountability. The principle of reciprocity implies respect for others and others' views, which also has specific consequences for the other principles. The principle of publicity implies that all circumstances and arguments must be known to everyone, precisely because of the principle of reciprocity. And the principle of accountability implies that everyone is accountable to everyone else.

The idea of deliberative democracy, as presented by Gutmann and Thompson (1996: 359), also underlines the need for the education of deliberative capacities among the citizens who will have the communicative power:

In any effort to make democracy more deliberative, the single most important institution outside government is the educational system. To prepare their students for citizenship, schools must go beyond teaching literacy and numeracy, though both are of course prerequisites for deliberating about public problems. Schools should aim to develop their students' capacities to understand different perspectives, communicate their understandings to other people, and 
engage in the give-and-take of moral argument with a view to making mutually acceptable decisions. These goals, which entail cultivating moral character and intellectual skills at the same time, are likely to require some significant changes in traditional civics education, which has neglected this kind of moral reasoning about politics.

\section{Deliberative communication in relation to learning theories}

Although civic education is emphasized in the previous quotation, there is no denying that the idea of deliberative communication, as I see it, can also be seen as relevant in a much broader perspective on learning activities related to almost all spheres of schooling. This view can also be traced back to the ideas of classical pragmatists such as Mead and Dewey. It can also be compared to one of the current challenges to the traditional school, the sociocultural perspective on learning (Nystrand 1997). ${ }^{6}$ This multifaceted approach represents a kind of renaissance for the theoretical perspectives elaborated by Russian thinkers like the psychologist Vygotsky, the theorist of literature Bakhtin, and many others. ${ }^{7}$ What is important here is that the sociocultural perspective on learning has emphasized the potential for communication in the classroom, both the communication that is led by the teacher and also takes place among students without a teacher present.

I will now attempt to characterize the idea of deliberative communication in schools.

\section{Five characteristics of deliberative communication}

Deliberative communication implies communication in which:

(a) different views are confronted with one another and arguments for these different views are given time and space to be articulated and presented (Habermas 1987, 1996, Gutmann and Thompson 1996);

(b) there is tolerance and respect for the concrete other and participants learn to listen to the other person's argument (Habermas 1987, 1996, Benhabib 1992);

(c) elements of collective will-formation are present, i.e. an endeavour to reach consensus or at least temporary agreements or to draw attention to differences (Habermas 1987, 1996, Gutmann and Thompson 1996);

(d) authorities or traditional views (represented, for example, by parents and tradition) can be questioned, and there are opportunities to challenge one's own tradition (Gutmann 1987, Nussbaum 1997); and

(e) there is scope for students to communicate and deliberate without teacher control, i.e. for argumentative discussions between students with the aim of solving problems or shedding light on them from different points of view (Hoel 2001). 


\section{Characteristics (a)-(c): Different views, tolerance, respect and collective will-formation}

The first three characteristics of deliberative communication may be seen as its inner core. This core is concerned with the presence of communication in which different views are brought face-to-face and different arguments are articulated, but guided by an effort to reach a consensus in which the concrete other is always respected. The main elements of deliberative communication imply that differences of conceptions and views are exposed, that the presuppositions and foundations underlying these differences are clarified, and that arguments for the different views are presented. At the same time, deliberative communication implies that its participants endeavour to reach consensus or to come to some form of conclusion as to how the problem/the different views are to be, or should be, resolved and/or conceptualized and on what kind of foundation this agreement rests. Thus, deliberation may result in the conclusion that agreement cannot be reached, and this should result in a search for new starting points or angles of approach.

Different views may mean different things in different circumstances and contexts. The presence of different views is one of the fundamental elements in deliberative communication and in creating, in spite of the differences, common ground for discussion. This common ground can be called a discursive situation - and by that I mean that a discursive situation exists when there is a situated common frame of reference and where the fundamental conditions for understanding and respect are at hand, or can at least be developed in due course. The role of the teacher is crucial, since he or she (usually) has both the real authority (in terms of the necessary knowledge and perspectives) to determine the discursive conditions for dealing with the problem in question, and the formal authority to do so, which can always be misused. Here is perhaps the crucial key to the contingency and the possible realization of the practice of deliberative communication. Creating a discursive situation in the classroom, and having intuition and knowledge about whether this situation is at hand, are mainly a matter of the teacher's judgement, a matter of phronesis.

Does this mean that this kind of communication should be pursued? Yes, in general, because communication of this kind, in which differences in views are brought face-to-face or can be shown to exist, can also- to the degree that it can sustain the focus of those involved, i.e. more or less active participants or listeners-help to sharpen the reasoning and discrimination of each participant and lead to changes in standpoints and views, implying that active learning is happening at the same time. However, this does not mean that educational practice should without exception be concerned with deliberative communication-it is a question for the teacher, in collaboration with the students, to judge the suitability of deliberative communication in any given context.

Characteristics (a)-(c) represent basic aspects of the substantial and formal character of deliberative communication, aspects that can at the same time be interpreted procedurally. In other words, the presence of different views, in some form or another, respect for the concrete other, and the element of collective will-formation are basic components of deliberative 
communication. The dimension of conflict and confrontation (of different views) is substantially central to, and constitutive of, deliberative communication as a procedural phenomenon. This dimension implies both openly conflicting views and a search for and attempt to expose relatively minor differences, which are seen in deliberative communication as crucial to investigate and possibly to resolve.

The fundamental starting point of deliberative communication in relational terms is respect for the concrete other, and by extension the question arises whether all kinds of views and perspectives can and should be respected-e.g. fundamentalist opinions, anti-democratic views, etc.-and whether deliberative communication is still taking place where these types of views are present.

The main sources of characteristics (a)-(c) are Habermas's discourse theory and his idea of communicative rationality as a force for normative rationalization of the societal order, the critical development of certain aspects of his thinking by Benhabib (1992), and the value of deliberation in relation to the multicultural society (Benhabib 2002). In addition, the preconditions for deliberative democracy and its possible application to education, as defined by Gutmann and Thompson (1996), are important points of reference.

\section{Characteristic (d): Schools as weak publics}

This component of deliberative communication rests on the important assumption that schools are potential public spaces in which there is a preference for pluralism. The boundaries between public and private (with regard to different aspects of a person's life, etc.) are difficult to define exactly, but the obvious tendency in accordance with this component is to see the school as an integral part of the public sphere. For this to be possible, knowledge, perspectives, and values must be public in the sense that they can be challenged by other forms of knowledge, perspectives, and values. In this confrontation it is important to recognize the relative, contingent, and perspectivized character of knowledge. This implies that the principle of pluralism becomes a fundamental and crucial element of deliberative communication. Pluralism here means that different views of knowledge (and the contexts in which they can be seen) and different values concerning different issues must be presented and made visible. This will, it is hoped, contribute to developing the autonomy of the individual student, but an autonomy of a specific character: a public autonomy implying that the standpoints and perspectives of each person are related to a societal context.

This means that the school will not primarily be a companion to the values of the home; rather, it will be pluralistic. Schools in general, and each individual school, will present the different views and values concerning different questions which exist in society, and that arguments for and against will be clarified. One implication is that the values and views of the individual student (learned by socialization at home) may be challenged at school and that the different views will be confronted with each other. 
That authorities and traditional views may be challenged can, thus, be seen as a central component of deliberative communication. The school is seen as a public space in which different standpoints and views occurring in public debate will also be highlighted, even if they challenge a world of values that students bring with them from their homes. Equally, teachers' opinions - especially if they leave no space for pluralism-may of course be questioned, challenged, and relativized in the same way.

This aspect of pluralism is fundamental, because it makes use of the institutionalized educational space and moment precisely as a public space in which all views, especially those that can be seen as authoritative, can be questioned. Crucial points to be remembered here are the need for respect for others (e.g. minorities) and the role of the teacher: what kind of values can be made public in what contexts (depending on the students' age, the climate in the classroom, etc.). ${ }^{8}$

How should the question of teacher authority be dealt with? Although the teacher has formal and (usually) also real authority, it is important that this authority rests on arguments, which of course implies different consequences, depending on the subject, etc. In many circumstances, authority is dependent on laws and different sets of rules, but these laws and rules may themselves be the subject of deliberation, e.g. through a questioning and discussion of the (historically-determined) tasks and forms of activity of different institutions.

With regard to all of the characteristics (a)-(d), the role of the teacher is central and crucial when it comes to management, power, responsibility, and judgement. In almost all cases, it is the teacher who has to make professional judgements about the possibility and suitability of initiating, authorizing, and conducting (or continuing) deliberative communication, and if necessary about bringing it to an end if it seems to be unsuccessful or has been pursued as far as it can. The students are very important team-workers, as both actively-talking and actively-listening participants, but it is the teacher who has the crucial role with regard to the direction, possible continuation, and conclusion of deliberative communication.

In what will be developed as the last component of deliberative communication, the role of the teacher is still central, but now it is more a question of managing, planning, and controlling. Characteristic (e) is about finding ways of promoting different forms of (deliberative) communication among the students when the teacher is not an active participant, and indeed not present at all.

\section{Characteristic (e): Deliberation among students without teacher control}

This last component is concerned with creating pre-conditions for (deliberative) communication among students. This communication may have the same characteristics as discussed above, but here the communication is accomplished without the management or presence of the teacher. In concrete terms, this kind of (deliberative) communication between students may be similar to and initiated as a kind of group project or as some sort of 
exploratory or preparatory communication (related to different kinds of tasks). It may also be based on some sort of common text-work and analysis, or consist of a confrontation of one student group's critical reading and analysis of a text with that of another group. These types of activities may of course be undertaken by e-mail, and not necessarily face-to-face.

Component (e) is distinguished from the others by the way it stresses verbal and written communication among students about student texts, etc. The idea is not new. In one sense, the idea of deliberative communication of this kind revitalizes a progressive tradition that seems to have been forgotten (the systematic use of students relating to each other with regard to different texts, and communicating and clarifying meaning). However, what is important in this context is that the (deliberative) communication that takes place among students supplements that are sketched out in characteristics (a)-(d).

However, why is it so crucial to develop this component-deliberative communication in the absence of the teacher? Many arguments could be advanced, but perhaps the most important one is that this kind of communication (among students, but related to (a)-(d)) is one in which meaning is created. Meaning for the individual student is created through interactive communication processes with other students, involving the student's own attempts to formulate his or her views and arguments on a specific question, listening to others, and being presented with counter-arguments, reformulations, etc. These are processes that take place among, if not equals, then contemporaries. This means that the pre-conditions for 'communicative equality' are different from the situation in the classroom, where the teacher is generally an authority.

However, what I want to emphasize concerning (deliberative) communication among students is its directed, content-related character, the need for it to be related to a definite theme or content - which it is up to the participants to evaluate, but which is at the same guided by the authority of the teacher, even if the direction the communication takes cannot be fully controlled. This interactive process - a meaning-creating process among equals - can, as has been pointed out, also be based on texts written by those participating in the process.

The basic inspiration for this kind of (deliberative) communication among students comes from a sociocultural perspective on learning. ${ }^{9}$ However, as already noted, it can also be seen as a renaissance for progressive, activity-based ideas going back to the early pragmatists. And, as I have suggested, it is in fact pragmatists like Dewey and Mead who are the primary sources of inspiration for the whole idea of deliberative communication and, with regard to characteristic (e), for the idea of making use of the 'social instinct of the children as shown in conversation, personal intercourse, and communication' (Dewey 1976: 29).

A final comment: characteristic (e) can be seen as the most crucial in a future educational situation which will require that use be made (e.g. for deliberative communication) not only of teacher-free time in schools, but also of time in which students are motivated to reconstruct and continue the theme initiated in an institutionalized deliberative communication. True, this already happens today, but if it is to happen more often and on a higher level, schools should be viewed increasingly as weak publics, closely related 
to ongoing developments in the surrounding multi-cultural society and involved in a continuing process of deliberation.

\section{Acknowledgements}

This paper, like the others in this issue of $\mathcal{F C S}$, was presented at the AERA convention in Chicago in 2003, as part of the symposium 'Deliberative communication: Applying Habermas to education'. The title of my paper at that time was 'Characteristics of deliberative communication - a pragmatist proposal'. The paper was also presented, in a similar form, at the 2003 Nordic Educational Research Association (NERA) Conference in Copenhagen, Denmark, and at the 2003 European Education Research Association Conference in Hamburg, Germany. All four of us (the authors of this and the following three papers) wish to express our thanks for the penetrating critique of our papers given by Nicholas Burbules, critic at AERA, and also to the editor of $\mathcal{F C S}$, Ian Westbury. This paper and the following papers by Carleheden (2006) and Boman (2006) are produced within the project 'Education as deliberative communication - pre-conditions, possibilities and consequences' financed by the Swedish Research Council.

\section{Notes}

1. In using the term 'democratic conception of education', I am making a two-fold reference, first to chapter 7 of Dewey's (1980) Democracy and Education and second to my own Curriculum as a Political Problem (Englund 1986), where I develop a democratic conception of education as a third educational conception in the history of education in Sweden (the first two being referred to as 'patriarchal' and 'scientific-rational'). In my 'The public and the text' (Englund 1996: 12) the democratic conception of education is seen and presented as an educational and political philosophical project, and this is what is developed further in the present series of papers, which also refer to the other educational conceptions mentioned.

2. This paper extends a short earlier presentation (Englund 2000b), produced on the initiative of the Swedish National Agency for Education. One elaboration of the idea was presented to the NERA conference in Stockholm (Englund 2001). The concept of deliberative communication was originally developed in two earlier papers (Englund 1998, 1999a).

3. The development of this concept has been multi-faceted. It is used by the US political scientist Besette (1980) and has subsequently been developed and given different authoritative interpretations by Manin (1987) and Cohen (1989) and, during the 1990s, by Rawls (1993), Habermas (1996), and Elster (1998). Current overviews are provided by Bohman and Rehg (1997) and Dryzek (2000).

4. Among representative researchers in this tradition one can mention classical figures such as J. J. Rousseau, J. S. Mill, and G. D. H. Cole and, among current names, Carole Pateman, Benjamin Barber, and Robert Bellah.

5. Representative researchers include Jürgen Habermas, Amy Gutmann, Dennis Thompson, David Miller, Joshua Cohen, and John Dryzek.

6. I will not elaborate further on this question here, but merely stress that such a perspective emphasizes learning through communication.

7. The educational use of these perspectives has, among other matters, been concerned with the relationship between scientific and commonplace concepts, implying a criticism of the tradition prevailing within science education.

8. There are many important sources of inspiration for this component of pluralism, but from the recent literature and debate in which authorities and traditions have been 
questioned and the view of education as a public space has been underlined, I mention Gutmann (1987) and Nussbaum (1997). Their ideas are not original, but both of them have clearly articulated-Gutmann with regard to comprehensive schools, and Nussbaum in the case of higher education - the need to make use of the educational space to move from the private (good) to the public (good), in a process where one's own values and statements may be tested in argumentation against those of others.

9. I have been primarily inspired by its development by Norwegian mother-tongue didacticians such as Dysthe $(1996,2002)$ and Hoel (2001).

\section{References}

Aristotle (1991) On Rhetoric: A Theory of Civic Discourse, trans. G. A. Kennedy (New York: Oxford University Press).

Aristotle (2002) Nicomachean Ethics, trans. S. Broadie and C. Rowe (Oxford: Oxford University Press).

Benhabib, S. (1992) Situating the Self: Gender, Community and Postmodernism in Contemporary Ethics (Cambridge: Polity Press).

Benhabib, S. (2002) The Claims of Culture: Equality and Diversity in the Global Era (Princeton, NJ: Princeton University Press).

Besette, J. M. (1980) Deliberative democracy: the majority principle in republican government. In R. A. Goldwin and W. A. Schambra (eds), How Democratic Is the Constitution? (Washington, DC: American Enterprise Institute for Public Policy Research), 102-116.

Bohman, J. and Rehg, W. (eds) (1997) Deliberative Democracy: Essays on Reason and Politics (Cambridge, MA: MIT Press).

Boman, Y. (2006) The struggle between conflicting beliefs: on the promise of education. fournal of Curriculum Studies, 38(5), 545-568.

Carleheden, M. (1996) Det andra moderna: om fürgen Habermas och den samhällsteoretiska diskursen om det andra moderna [The second modernity: about Jürgen Habermas and the social science discourse about the second modernity] (Göteborg, Sweden: Daidalos].

Carleheden, M. (2006) Towards democratic foundations: a Habermasian perspective on the politics of education. Fournal of Curriculum Studies, 38(5), 521-543.

Cohen, J. (1989) Deliberation and democratic legitimacy. In A. Hamlin and P. Pettit (eds), The Good Polity: Normative Analysis of the State (Oxford: Basil Blackwell), 17-34.

Dewey, J. (1976 [1899]) The school and society. In J. Dewey (ed.), The Middle Works 18991924: Volume 1: 1899-1901, ed. J. A. Boydston (Carbondale, IL: Southern Illinois University Press), 1-237.

Dewey, J. (1980 [1916]) Democracy and education. In J. Dewey (ed.), The Middle Works, 1899-1924: Volume 9: 1916, ed. J. A. Boydston (Carbondale, IL: Southern Illinois University Press).

Dewey, J. (1984 [1927]) The public and its problems. In J. Dewey (ed.), The Later Works, 1925-1953: Volume 2: 1925-1927, ed. J. A. Boydston (Carbondale, IL: Southern Illinois Press), 235-372.

Dryzek, J. S. (2000) Deliberative Democracy and Beyond: Liberals, Critics, Contestations (Oxford: Oxford University Press).

Durkheim, E. (1961 [1912]) The Elementary Forms of the Religious Life, trans. J. W Swain (New York: Collier).

Dysthe, O. (1996) Det flerstämmiga klassrummet [A classroom with many voices] (Lund, Sweden: Studentlitteratur).

Dysthe, O. (ed.) (2002) Dialog, samspel och lärande [Dialogue, collaboration and learning] (Lund, Sweden: Studentlitteratur).

Elster, J. (ed.) (1998) Deliberative Democracy (New York: Cambridge University Press).

Englund, T. (1986) Curriculum as a Political Problem: Changing Educational Conceptions with Special Reference to Citizenship Education Uppsala Studies in Education 25 (Lund, Sweden: Studentlitteratur/Chartwell-Bratt).

Englund, T. (1996) The public and the text. Fournal of Curriculum Studies, 28(1), 1-35. 
Englund, T. (1998) Varför ett sociopolitiskt perspektiv på det vi kallar undervisning och lärande? [Why a sociopolitical perspective on what we call teaching and learning?] Utbildning och demokrati: Tidskrift för didaktik och utbildningspolitik, 7(2), 5-14.

Englund, T. (1999a) Den svenska skolan och demokratin - möjligheter och begränsningar [The Swedish school and democracy_possibilities and constraints]. In SOU 1999:93, Det unga folkstyret: Demokratiutredningens forskarvolym VI [Swedish Government Official Reports 1999:93, Young democracy. Research volume VI of the Swedish Democracy Commission], 13-50.

Englund, T. (1999b) Om John Dewey och Demokrati och utbildning [About John Dewey and Democracy and Education]. In J. Dewey (ed.) [1916] Demokratioch utbildning [Democracy and Education] (Göteborg, Sweden: Daidalos).

Englund, T. (2000a) Rethinking democracy and education: towards an education of deliberative citizens. Fournal of Curriculum Studies, 32(2), 305-313.

Englund, T. (2000b) Deliberativa samtal som värdegrund-historiska perspektiv och aktuella förutsättningar [Deliberative communication as a value foundation-historical perspectives and current preconditions] (Stockholm: Skolverket).

Englund, T. (2001) Deliberativa samtal—en utgångspunkt för en läroplansarkitektur i det andra moderna? [Deliberative conversations - a starting point for a curriculum architecture in the second modernity?] Paper presented at the conference of the Nordic Educational Research Association, Stockholm.

Englund, T. (2002) Utbildning som medborgerlig rättighet-Skilda traditioner och uttolkningsmöjligheter [Education as a citizenship right-Different traditions and possibilities of interpretations]. Utbildning \& Demokrati: Tidskrift för didaktik och utbildningspolitik, 11(1), 111-120.

Eriksen, E. O. and Weigård, J. (2000) Habermas politiska teori [The political theory of Habermas] (Lund, Sweden: Studentlitteratur).

Fraser, N. (1992) Rethinking the public sphere: a contribution to the critique of actually existing democracy. In C. Calhoun (ed.), Habermas and the Public Sphere (Cambridge, MA: MIT Press), 109-142.

Gutmann, A. (1987) Democratic Education (Princeton, NJ: Princeton University Press).

Gutmann, A. and Thompson, D. (1996) Democracy and Disagreement (Cambridge, MA: Belknap Press).

Habermas, J. (1984) The Theory of Communicative Action, Vol. 1: Reason and the Rationalization of Society, trans T. McCarthy (Boston: Beacon Press).

Habermas, J. (1987) The Theory of Communicative Action, Vol. 2: Lifeworld and System: A Critique of Functionalist Reason, trans T. McCarthy (Boston: Beacon Press).

Habermas, J. (1990) The Philosophical Discourse of Modernity: Twelve Lectures, trans. F. G. Lawrence (Cambridge: Polity Press).

Habermas, J. (1996 [1992 in German]) Between Facts and Norms: Contributions to a Discourse Theory of Law and Democracy, trans. W. Rehg (Cambridge: Polity Press).

Hoel, T. L. (2001) Skriva och samtala: Lärande genom responsgrupper [Writing and conversing: learning through response groups] (Lund, Sweden: Studentlitteratur).

Knight, J. and Johnson, J. (1997) What sort of political equality does deliberative democracy require? In J. Bohman and W. Rehg (eds), Deliberative Democracy: Essays on Reason and Politics (Cambridge, MA: MIT Press), 279-319.

Lewin, L. (1970) Folket och eliterna [The people and the elites] (Stockholm: Almqvist \& Wiksell).

Ljunggren, C. (1996a) Medborgarpubliken och det offentliga rummet: Om utbildning, medier och demokrati [The public and its need to define itself: on education, the media and democracy]. Uppsala Studies in Education 68 (Lund, Sweden: Almquist \& Wiksell).

Ljunggren, C. (1996b) Education, media and democracy: on communication and the nature of the public in the light of John Dewey, Walter Lippmann, and the discussion of modernity. Fournal of Curriculum Studies, 28(1), 73-90.

Lpo 94 (1994) Läroplan för det obligatoriska skolväsendet och de frivilliga skolformerna [1994 Syllabus for the compulsory comprehensive school system and the voluntary schools] (Stockholm: Utbildnings departementet).

Manin, B. (1987) On legitimacy and political deliberation. Political Theory, 15(3), 338-368. 
Marshall, T. H. (1964 [1949]) Class, Citizenship and Social Development: Essays (Garden City, NY: Doubleday).

Ministry of Education (2000) Värdegrundsboken: Om samtal för demokrati $i$ skolan [A book about basic values: conversation as a tool for democracy in schools] (Stockholm: Utbildnings departementet).

National Agency for Education (2000) En fördjupad studie om värdegrunden-om möten, relationer och samtal som förutsättningar för arbetet med de grundläggande värdena, Dnr 2000:1613 [An in-depth study of the value foundation of schools-encounters, relationships and conversations as necessary conditions for the development of basic values] (Stockholm: Skolverket).

Nussbaum, M. (1997) Cultivating Humanity: A Classical Defense of Reform in Liberal Education (Cambridge, MA: Harvard University Press).

Nystrand, M. (1997) Opening Dialogue: Understanding the Dynamics of Language and Learning in the English Classroom (New York: Teachers College Press).

Rawls, J. (1993) Political Liberalism (New York: Columbia University Press).

Reese-Schäfer, W. (1995) Fürgen Habermas - en introduktion [Jürgen Habermas-an introduction] (Göteborg, Sweden: Daidalos).

von Wright, M. (2000) Vad eller vem? En pedagogisk rekonstruktion av G. H. Meads teori om människors intersubjektivitet [What or who? A pedagogical reconstruction of G. H. Mead's theory about human intersubjectivity]. (Göteborg, Sweden: Daidalos). 
Copyright of Journal of Curriculum Studies is the property of Routledge and its content may not be copied or emailed to multiple sites or posted to a listserv without the copyright holder's express written permission. However, users may print, download, or email articles for individual use. 